\title{
Seedlings production and fruit yield of cucumber on different organic substrates
}

\section{Laís de Lima Luqui ${ }^{1}$, Josiane Souza Salles ${ }^{2}$, Edilson Costa ${ }^{2}$, Vitória Carolina Dantas Alves ${ }^{2}$, Larissa Gabriela Pereira de Souza², Mariane Tavares Vieira², Jussara Souza Salles², Vitória Cristina Di Matheus e Souza ${ }^{2}$}

${ }^{1}$ Universidade Estadual de Mato Grosso do Sul, Unidade Universitária de Aquidauana, Aquidauana, Mato Grosso do Sul, Brasil. E-mail: lais_luqui@hotmail.com

${ }^{2}$ Universidade Estadual de Mato Grosso do Sul, Unidade Universitária de Cassilândia, Cassilândia, Mato Grosso do Sul, Brasil. E-mail: josi_souzasalles@hotmail.com, mestrine@uems.br, vi-alves99@live.com, larigpsouza@gmail.com, marianetavs@gmail.com, jus_sarasalles@hotmail.com,vitoriacdms@gmail.com

Received: 30/04/2019; Accepted: 14/08/2019.

\section{ABSTRACT}

Demand for agricultural products with zero or reduced amounts of agrochemicals leads to increasingly healthy production alternatives. Thus, seedling formation and fruit yield of three cucumber cultivars were evaluated on different organic substrates in a protected environment. Marketer, Caipira and Verde Comprido cultivars were grown on five substrates: $100 \%$ cassava stems $+0 \%$ cattle manure; $75 \%$ cassava stems $+25 \%$ cattle manure; $50 \%$ cassava stems $+50 \%$ cattle manure $25 \%$ cassava stems $+75 \%$ cattle manure and $0 \%$ cassava stems $+100 \%$ cattle manure. A completely randomized design in a 5 x 3 factorial scheme ( 5 substrates X 3 cultivars) was used, with six replications of four seedlings in the seedling formation phase and five replications of two plants in the fruit production phase. The seedlings were produced in trays with 72 cells, and fruit production was conducted in 13liter pots. There was a little influence of the substrates on the emergence of cucumber cultivars: the substrates with 75 and $100 \%$ of cattle manure provided the best conditions for seedling formation, as well as the highest yield and the largest amount of fruits. On the best substrates, the cultivar Caipira had fruits with higher mass and larger average fruit diameter, but in smaller numbers.

Keywords: Cucumis sativus, protected cultivation, cattle manure, cassava stems.

\section{Produção de mudas e frutos de pepino em diferentes substratos orgânicos}

\section{RESUMO}

A procura de produtos agrícolas com quantidade zero ou reduzida de agroquímico faz com que se busquem alternativas de produção cada vez mais saudáveis. Dessa forma, avaliou-se a formação de mudas e a produção de frutos de três cultivares de pepineiro em diferentes substratos orgânicos no interior de ambiente protegido. Os cultivares Marketer, Caipira e Verde Comprido foram testados em cinco substratos: $100 \%$ de ramas de mandioca + $0 \%$ de esterco bovino; $75 \%$ de ramas de mandioca $+25 \%$ de esterco bovino; $50 \%$ de ramas de mandioca $+50 \%$ de esterco bovino; $25 \%$ de ramas de mandioca $+75 \%$ de esterco bovino e $0 \%$ de ramas de mandioca $+100 \%$ de esterco bovino. Foi utilizado o delineamento inteiramente casualizado em esquema fatorial 5 x 3 (5 substratos X 3 cultivares), com seis repetições de quatro plântulas na fase de formação das mudas e cinco repetições de duas plantas na fase de produção dos frutos. As mudas foram produzidas em bandejas de 72 células e a produção de frutos foi conduzida em vasos de 13 litros. Houve pequena influência dos substratos na emergência dos cultivares de pepineiro: o substrato com 75 e 100\% de esterco bovino propiciou as melhores condições para formação das mudas, assim como a melhor produção de frutos e a maior quantidade de frutos. O cultivar Caipira apresentou frutos com maior massa e maior diâmetro médio do fruto, porém, em menor número nos melhores substratos.

Palavras-chave: Cucumis sativus, cultivo protegido, esterco bovino, ramas de mandioca. 


\section{Introduction}

Vegetable seedlings for field or container production in protected environments must be uniform and of high quality. Quality directly influences the final performance of the plant and its yield (Setubal et al., 2004; Rodrigues et al., 2010), while low-quality seedlings can significantly increase the production cost and time (Guimarães et al., 2002; Echer et al., 2007).

Evaluation of the yield capacity of vegetable seedlings after substrate or container tests was performed by Modolo et al. (1999), Modolo et al. (2001) and Costa et al. (2013b) with okra, Leal et al. (2011) with lettuce and beets, and Costa et al. (2012a) and Costa et al. (2013a) with eggplant, and the results indicating that high-quality seedlings increase yield. In studies with 128-cell expanded polystyrene trays, Seabra Júnior et al. (2004) observed that the use of trays with larger volume $\left(121.2 \mathrm{~cm}^{3}\right)$ resulted in earlier fruit harvesting than seedlings grown in trays with smaller volume $\left(34.6 \mathrm{~cm}^{3}\right)$

The use of a single material for substrate composition may not meet the real requirements of the plant, and it is more viable to use mixtures (Araújo Neto et al., 2009). The use of organic materials in a substrate formulation improves its permeability, contributes to mineral particle aggregation and acidity correction (Miranda et al., 1998). Earthworm humus and animal manure are widely used in substrates by vegetable producers (Costa et al., 2009). Cattle manure may partially replace mineral fertilizer as a source of nutrients (Rodrigues et al., 2008). Substrate composition must also value the use of local material, of low cost, organic and reliable origin. These benefits both the producer and sustainability in agriculture.

Studies evaluating the formation of cucumber seedlings were developed by Smiderle et al. (2001), Cañizares et al. (2002), Costa et al. (2010), and Costa et al. (2012b); however, the seedlings productive capacity was not verified. According to Carrijo et al. (2004), the production in protected cultivation is easier to handle than in the field, besides allowing better conditions of plant production. With market demands and the need to eat healthily, the demand for agricultural products with reliable origins and with little or no agrochemicals has increased. Producers have specialized and sought to meet this promising market, given the possible improvements in profitability per unit of production. Thus, we aimed to evaluate the formation of cucumber seedlings in different organic substrates, as well as their fruit yield in pots, both in a protected environment.

\section{Material and Methods}

Experiments with different substrates to grow cucumber cultivars were conducted at the Mato Grosso do Sul State University (UEMS), in Aquidauana, MS, $\left(55^{\circ} 48^{\prime} 00^{\prime \prime} \mathrm{W}, 20^{\circ} 20^{\prime} 00^{\prime \prime} \mathrm{S}\right.$ and altitude of $200 \mathrm{~m}$ ), in 2011. Seedling formation and fruit yield were evaluated under protected environment conditions.

The protected environment used had $8.00 \mathrm{~m}$ wide $\mathrm{x}$ $18.00 \mathrm{~m}$ long x $4.00 \mathrm{~m}$ high, galvanized steel structure, with a zenithal opening in the ridge, $150 \mu \mathrm{m}$ polyethylene film cover and thermo-reflector screen with $50 \%$ shading under the film, with side and front closures with monofilament.

\section{Seedling formation in trays}

Seedlings of following cultivars, Marketer, Caipira and Verde Comprido were tested on the following substrates: $100 \%$ cassava stems (CS) $+0 \%$ cattle manure $(\mathrm{CM}) ; 75 \%$ cassava stems $+25 \%$ cattle manure; $50 \%$ cassava stems $+50 \%$ cattle manure; $25 \%$ cassava stems $+75 \%$ cattle manure, and $0 \%$ cassava stems + $100 \%$ cattle manure. For seedling formation 72-cell polystyrene trays (volume of $121.2 \mathrm{~cm}^{3}$ per cell) were used.

The seeds were sown on May 5th, 2011, and the emergence occurred on May 10th, 2011. From the emergence, the counting of the number of emerged seedlings was performed, and at 19 days after sowing (DAS) occurred the stabilization of the emergence. At this stage, the emergence speed index (ESI), the percentage of emergence (PE), the mean emergence time (MET), and the mean emergence speed (MES) were evaluated.

At 27 DAS, plant height (PH), stem diameter (SD), shoot dry matter (SDM), and root dry matter (RDM) were measured. Plant matter was dried in a forced-air oven at $65^{\circ} \mathrm{C}$ for 72 hours. The sum among SDM and RDM resulted in the total dry matter (TDM). The relationship between shoot and root dry matter (S:R), the relationship between plant height and stem diameter (H:D), the relationship between plant height and shoot dry matter $(\mathrm{H}: \mathrm{S})$, and the Dickson quality index (DQI = [TDM / (H:D + S:R)] were determined.

The experiment was conducted in a completely randomized design, in a $5 \times 3$ factorial scheme (five substrates $\mathrm{X}$ three cultivars), with six replications of four seedlings. Data were submitted to variance analysis using the Sisvar 5.3 statistical software, and the means were compared by Tukey test at $5 \%$ probability level.

\section{Fruit yield in pots}

At this experimental phase, the same substrates were used, except for the substrate, $100 \%$ cassava stems + $0 \%$ cattle manure, because there was an uneven development of the seedlings. Pots of 13.0 L were used to grow the cucumber seedlings. The transplant to the pots was performed at 28 days after sowing. The plants were conducted vertically in a single stem using 
tutoring, and one plant per pot was grown. Fruit mass $(\mathrm{kg})$, fruit length $(\mathrm{cm})$, fruit diameter $(\mathrm{mm})$, number of fruits, and yield per plant were measured.

The experiment was conducted in a completely randomized design in a $5 \times 3$ factorial scheme (five substrates $X$ three cultivars), with five replications of two pots. Data were submitted to variance analysis by the Sisvar 5.3 statistical software. The means were compared by Tukey test at $5 \%$ probability level.

\section{Results and Discussion Seedlings formation}

There was no significant interaction between substrates and cucumber cultivars factors for emergence speed index, percentage of emergence, plant height, root dry matter, total dry matter, the relationship between plant height and stem diameter, and the relationship between shoot and root dry matter of cucumber seedlings. Thus, the influence of isolated factors was observed for these variables (Table 1).

The highest percentage of emergence was verified in the cultivar Verde Comprido, and the dry matter of cultivars did not differ between them (Table 1). Higher mean emergence speed and percentage of emergence were observed in seedlings grown on the substrate containing $50 \%$ of each component: cassava stems (CS) + cattle manure $(\mathrm{CM})$ when compared to seedlings grown on the substrate containing $75 \% \mathrm{CS}+25 \% \mathrm{CM}$ (Table 1). For this phase, the median composition favored the seedling radicle emission, with the cassava stems providing physical structure and the cattle manure, water adsorption due to the presence of organic matter. Similar to this result, Costa et al. (2011), when studying eggplant seedlings, observed that median proportions of cassava stems and vermiculite favored the emergence and development of these seedlings.

The variation of cattle manure from 0 to $50 \%$ resulted in lower values of SDM, not differing statistically from each other. Seedlings grown on substrates containing a higher proportion of manure, 75 and $100 \%$, had higher biomass accumulation in the cucumber cultivars, reflecting in a higher number of sprouts, roots and total dry matter (Table 1). Higher availability of nutrients, due to the higher amount of cattle manure, provided seedlings with the larger dry matter, unlike that observed by Oliveira et al. (2007), who evaluated the ratios of $0,10,20,30$ and $40 \%$ of manure in cucumber seedling formation. They observed for the shoot and total dry matter that the ratio of $30 \%$ of cattle manure limited the growth, and for root dry matter, the same occurred with $20 \%$ of cattle manure.

Table 1. Emergence speed index (ESI), percentage of emergency (PE), plant height (PH), shoot dry mass (SDM), root dry mass $(\mathrm{RDM})$, total dry mass (TDM), the relationship between shoot and root dry matter (S:R), and the relationship between plant height and stem diameter (H:D) of cucumber seedlings. Aquidauana-MS, UEMS, 2011.

\begin{tabular}{|c|c|c|c|c|}
\hline & ESI & PE (\%) & $\mathrm{PH}(\mathrm{cm})$ & $\operatorname{SDM}(\mathrm{g})$ \\
\hline & \multicolumn{4}{|c|}{ Substrates } \\
\hline $100 \% \mathrm{CS}+0 \% \mathrm{CM}$ & $29.26 \mathrm{AB}^{*}$ & $57.64 \mathrm{AB}$ & $2.73 \mathrm{C}$ & $0.0972 \mathrm{C}$ \\
\hline $75 \% \mathrm{CS}+25 \% \mathrm{CM}$ & 26.65 B & $52.78 \mathrm{~B}$ & $3.03 \mathrm{C}$ & $0.1045 \mathrm{C}$ \\
\hline $50 \% \mathrm{CS}+50 \% \mathrm{CM}$ & $35.02 \mathrm{~A}$ & $64.58 \mathrm{~A}$ & $3.07 \mathrm{C}$ & $0.1246 \mathrm{C}$ \\
\hline $25 \% \mathrm{CS}+75 \% \mathrm{CM}$ & $31.39 \mathrm{AB}$ & $58.91 \mathrm{AB}$ & $4.74 \mathrm{~B}$ & $0.2179 \mathrm{~B}$ \\
\hline \multirow[t]{2}{*}{$0 \% \mathrm{CS}+100 \% \mathrm{CM}$} & $27.80 \mathrm{AB}$ & $53.47 \mathrm{~B}$ & $6.36 \mathrm{~A}$ & $0.3211 \mathrm{~A}$ \\
\hline & \multicolumn{4}{|c|}{ Cultivars } \\
\hline Marketer & $30.89 \mathrm{~A}$ & $52.50 \mathrm{~B}$ & $3.52 \mathrm{~B}$ & $0.1802 \mathrm{~A}$ \\
\hline Caipira & $24.56 \mathrm{~B}$ & $50.49 \mathrm{~B}$ & $4.40 \mathrm{~A}$ & $0.1803 \mathrm{~A}$ \\
\hline Verde Comprido & $34.63 \mathrm{~A}$ & $69.44 \mathrm{~A}$ & $4.04 \mathrm{AB}$ & $0.1587 \mathrm{~A}$ \\
\hline $\mathrm{CV}(\%)$ & 26.37 & 19.95 & 26.04 & 23.51 \\
\hline \multirow[t]{3}{*}{$\mathrm{Pr}>\mathrm{Fc}$} & 0.0606 & 0.0854 & 0.0920 & 0.2849 \\
\hline & $\mathrm{SDM}(\mathrm{g})$ & TDM $(\mathrm{g})$ & $\mathrm{H}: \mathrm{D}$ & $\mathrm{S}: \mathrm{R}$ \\
\hline & \multicolumn{4}{|c|}{ Substrates } \\
\hline $100 \% \mathrm{CS}+0 \% \mathrm{CM}$ & $0.0200 \mathrm{C}$ & $0.1172 \mathrm{C}$ & $1.18 \mathrm{~A}$ & $5.11 \mathrm{~A}$ \\
\hline $75 \% \mathrm{CS}+25 \% \mathrm{CM}$ & $0.0198 \mathrm{C}$ & $0.1244 \mathrm{C}$ & $1.36 \mathrm{~A}$ & $5.53 \mathrm{~A}$ \\
\hline $50 \% \mathrm{CS}+50 \% \mathrm{CM}$ & $0.0257 \mathrm{C}$ & $0.1503 \mathrm{C}$ & $1.35 \mathrm{~A}$ & $5.02 \mathrm{~A}$ \\
\hline $25 \% \mathrm{CS}+75 \% \mathrm{CM}$ & $0.0419 \mathrm{~B}$ & $0.2598 \mathrm{~B}$ & $1.27 \mathrm{~A}$ & $5.31 \mathrm{~A}$ \\
\hline \multirow[t]{2}{*}{$0 \% \mathrm{CS}+100 \% \mathrm{CM}$} & $0.0535 \mathrm{~A}$ & $0.3746 \mathrm{~A}$ & $1.39 \mathrm{~A}$ & $6.23 \mathrm{~A}$ \\
\hline & \multicolumn{4}{|c|}{ Cultivars } \\
\hline Marketer & $0.0342 \mathrm{~A}$ & $0.2144 \mathrm{~A}$ & $1.22 \mathrm{~A}$ & $5.40 \mathrm{~A}$ \\
\hline Caipira & $0.0315 \mathrm{~A}$ & $0.2119 \mathrm{~A}$ & $1.35 \mathrm{~A}$ & $5.83 \mathrm{~A}$ \\
\hline Verde comprido & $0.0307 \mathrm{~A}$ & $0.1894 \mathrm{~A}$ & $1.36 \mathrm{~A}$ & $5.09 \mathrm{~A}$ \\
\hline $\mathrm{CV}(\%)$ & 24.20 & 21.63 & 18.62 & 24.83 \\
\hline $\mathrm{Pr}>\mathrm{Fc}$ & 0.1195 & 0.2873 & 0.1444 & 0.0610 \\
\hline
\end{tabular}

*Equal uppercase letters in the columns do not differ from each other by the Tukey test at $5 \%$ probability level; CV = coefficient of variation; $\mathrm{CS}=$ cassava stems; $\mathrm{CM}=$ cattle manure; $\mathrm{Pr}=$ probability; $\mathrm{Fc}=\mathrm{F}$ calculated. 
For the mean emergence time, there was no difference as a function of the substrates used for the Caipira and Verde Comprido cultivars, only for the Marketer variety, which presented the shortest mean emergence time when sown in the substrate containing $50 \% \mathrm{CS}+50 \% \mathrm{CM}$, not differing from the substrates: $100 \% \mathrm{CS}+0 \% \mathrm{CM}$ and $25 \% \mathrm{CS}+75 \% \mathrm{CM}$. There was the difference between the cultivars only in substrates $100 \% \mathrm{CS}+0 \% \mathrm{CM}$ and $50 \% \mathrm{CS}+50 \% \mathrm{CM}$, in which the Marketer cultivar had the lowest mean emergence time, with an average of 12.8 days. The same behavior was observed for mean emergence speed, in which the treatments with the shortest mean emergence time consequently had higher mean emergence speed (Table 2).

Aiming not to promote the error of selecting larger but weak seedlings, discarding truly vigorous seedlings, the variables of study should not be analyzed in isolation to evaluate seedling quality. Biometric relationships such as the relationship between plant height and stem diameter (H:D), and the Dickson quality index (DQI) are used to estimate seedling quality. The H:D determines the balance between growth in plant height and thickness, so the lower the ratio, the less probability it occurs etiolation after transplantation. For DQI, the higher, the better, as it considers the balance of growth distribution, such as height, diameter, and dry matter, jointly evaluating the variables that define the final quality of the seedling (Fonseca et al., 2002; Gomes and Paiva, 2012).

The highest DQI and H:D values were found, for all cultivars, in seedlings produced in the substrate with a higher amount of cattle manure $(0 \% \mathrm{CS}+100 \% \mathrm{CM})$. In this substrate, the cultivar Marketer had high quality, indicated by DQI (Table 2). The higher amounts of cattle manure, due to the higher amount of nutrients, were favorable to obtain high-quality cucumber seedlings.

The seedlings showed no differences in the relationship between shoot and root dry matter (S:R), and the relationship between plant height and stem diameter (H:D) in the substrates tested (Table 2). The mean H:D was 1.31 , showing that the growth in height was proportional to the growth in diameter and the seedlings showed no symptoms of etiolation. For tomato seedlings, Rodrigues et al. (2010) found a mean H:D of 3.61, at 33 DAS.

In studies about the production of Garcinia humilis seedlings at different shading levels and substrates, Silva et al. $(2018 \mathrm{a}, 2018 \mathrm{~b})$ report that the choice of seedlings should not be made through isolated variables, and the Dickson quality index (DQI) is a reliable variable to indicate the quality of the seedlings. DQI is based on the relationship of some growth variables, informing that seedlings with high-Quality indexes were formed from different substrate compositions. As in research by Salles et al. (2017) for seedling production of jambolan (Syzygium cumini), in which H:D and DQI values were essential for determining the quality of the seedlings. The treatments that promoted seedlings with higher DQI were the ones that promoted the largest diameter, and the highest dry matter of shoot and total, and the lowest H:D values of seedlings (Salles et al., 2017).

Table 2. Interactions between substrates and cultivars for mean emergence time, mean emergence speed, stem diameter, and Dickson quality index of cucumber seedlings. Aquidauana-MS, UEMS, 2011.

\begin{tabular}{|c|c|c|c|c|c|c|}
\hline & Marketer & Caipira & $\begin{array}{c}\text { Verde } \\
\text { comprido }\end{array}$ & Marketer & Caipira & $\begin{array}{c}\text { Verde } \\
\text { comprido }\end{array}$ \\
\hline & \multicolumn{3}{|c|}{------------MET (days)-----------' } & \multicolumn{3}{|c|}{-----------MES $\left(\right.$ days $\left.^{-1}\right)$---------- } \\
\hline $100 \% \mathrm{CS}+0 \% \mathrm{CM}$ & $12.8 \mathrm{ABb}^{*}$ & $13.4 \mathrm{Aa}$ & $13.3 \mathrm{Aa}$ & $0.079 \mathrm{Aba}$ & $0.075 \mathrm{Ab}$ & $0.075 \mathrm{Ab}$ \\
\hline $75 \% \mathrm{CS}+25 \% \mathrm{CM}$ & $13.0 \mathrm{Aa}$ & $13.1 \mathrm{Aa}$ & $13.3 \mathrm{Aa}$ & $0.077 \mathrm{Ba}$ & $0.077 \mathrm{Aa}$ & $0.076 \mathrm{Aa}$ \\
\hline $50 \% \mathrm{CS}+50 \% \mathrm{CM}$ & $12.4 \mathrm{Bb}$ & $13.1 \mathrm{Aa}$ & $13.2 \mathrm{Aa}$ & $0.081 \mathrm{Aa}$ & $0.076 \mathrm{Ab}$ & $0.076 \mathrm{Ab}$ \\
\hline $25 \% \mathrm{CS}+75 \% \mathrm{CM}$ & $12.8 \mathrm{Aba}$ & $13.2 \mathrm{Aa}$ & $12.9 \mathrm{Aa}$ & $0.078 \mathrm{Aba}$ & $0.076 \mathrm{Aa}$ & $0.077 \mathrm{Aa}$ \\
\hline $0 \% \mathrm{CS}+100 \% \mathrm{CM}$ & $13.2 \mathrm{Aa}$ & 13.1 Aa & 13.1 Aa & $0.076 \mathrm{Ba}$ & $0.076 \mathrm{Aa}$ & $0.076 \mathrm{Aa}$ \\
\hline $\mathrm{CV}(\%)$ & & 2.58 & & & 2.55 & \\
\hline \multirow[t]{2}{*}{$\mathrm{Pr}>\mathrm{Fc}$} & & 0.0202 & & & 0.0177 & \\
\hline & \multicolumn{3}{|c|}{ - SD (mm) - - } & \multicolumn{3}{|c|}{-------------- DQI -------------- } \\
\hline $100 \% \mathrm{CS}+0 \% \mathrm{CM}$ & $1.96 \mathrm{Cb}$ & $2.58 \mathrm{Ca}$ & $2.41 \mathrm{Ca}$ & $0.022 \mathrm{Ca}$ & $0.018 \mathrm{Ba}$ & $0.019 \mathrm{Ba}$ \\
\hline $75 \% \mathrm{CS}+25 \% \mathrm{CM}$ & $2.17 \mathrm{Ca}$ & $2.43 \mathrm{Ca}$ & $2.07 \mathrm{Ca}$ & $0.017 \mathrm{Ca}$ & $0.020 \mathrm{Ba}$ & $0.019 \mathrm{Ba}$ \\
\hline $50 \% \mathrm{CS}+50 \% \mathrm{CM}$ & $2.05 \mathrm{Cb}$ & $2.66 \mathrm{Ca}$ & $2.15 \mathrm{Cb}$ & $0.022 \mathrm{Ca}$ & $0.026 \mathrm{Ba}$ & $0.024 \mathrm{Ba}$ \\
\hline $25 \% \mathrm{CS}+75 \% \mathrm{CM}$ & 3.66 Bab & $4.05 \mathrm{Ba}$ & $3.35 \mathrm{Bb}$ & $0.043 \mathrm{Ba}$ & $0.038 \mathrm{Aa}$ & $0.039 \mathrm{Aa}$ \\
\hline $0 \% \mathrm{CS}+100 \% \mathrm{CM}$ & $4.45 \mathrm{Aa}$ & $4.58 \mathrm{Aa}$ & $4.65 \mathrm{Aa}$ & $0.061 \mathrm{Aa}$ & $0.048 \mathrm{Ab}$ & $0.044 \mathrm{Ab}$ \\
\hline $\mathrm{CV}(\%)$ & & 10.63 & & & 23.74 & \\
\hline $\mathrm{Pr}>\mathrm{Fc}$ & & 0.0431 & & & 0.0454 & \\
\hline
\end{tabular}

*Equal uppercase letters in the columns and lowercase letters in the rows do not differ from each other by the Tukey test at $5 \%$ probability level; $\mathrm{CV}=$ coefficient of variation $; \mathrm{CS}=$ cassava stems; $\mathrm{CM}=$ cattle manure; $\mathrm{Pr}=$ probability $; \mathrm{Fc}=\mathrm{F}$ calculated . 


\section{Development and fruit yield}

Fruit mass, fruit diameter, and the number of fruits were influenced by the significant interaction between the two factors studied; however, the yield per plant was influenced only by the substrates (Table 3 ).

The cultivar Caipira produced a larger number of fruits and fruits with higher mass and larger average diameter on the substrates with $75 \%$ and $100 \%$ of cattle manure. Marketer and Verde Comprido cultivars had no differences in fruit mass and diameter; however, a higher number of fruits were found in the same substrates observed for Caipira cultivar, as well as the highest yield per plant for the three cultivars (Table 3).

The cucumber grown on the substrate containing $100 \%$ of cattle manure had yield of $1,395 \mathrm{~kg} \mathrm{plant}^{-1}$ (average of cultivars), 8.50 fruits per plant (Verde Comprido) and fruits with 230 grams (Caipira). For the substrate with $75 \%$ of cattle manure, 10.6 fruits per plant were obtained for the cultivar Marketer (Table 3). These results were inferior to those obtained by Fernandes et al. (2002), who observed yield of $3.46 \mathrm{~kg}$ plant $^{-1}, 13.2$ fruits per plant and fruit mass of 267.49 grams for cultivar Aodai, produced in $8.6 \mathrm{~L}$ pots using nutrient solution. Fruit diameter was similar (49.3 mm).

Antunes et al. (2014), studying the quality of African cucumber fruits in response to nitrogen fertilization in $10 \mathrm{~L}$ pots, found 2.24 fruits plant $^{-1}$ and $516.41 \mathrm{~g} \mathrm{plant}^{-1}$, respectively, at the doses of 122.50 and $154.44 \mathrm{~kg} \mathrm{~N}$ per hectare. The average fruit mass was $240.27 \mathrm{~g}$ fruit $^{-1}$, obtained with the highest tested dose (200 kg N per hectare). The number of fruits (2,24 fruits plant $^{-1}$ ) was much lower than the one obtained in the present study (10,6 fruits plant $\left.{ }^{-1}\right)$.

In the comparison of the cultivars, evaluating the substrate $25 \% \mathrm{CS}+75 \% \mathrm{CM}$, it was verified that the fruits of the cultivar Caipira had higher mass and larger diameters when compared to the fruits of the other cultivars. However, its production had the lowest number of fruits (Table 3).

Sediyama et al. (2012) tested cattle manure at doses of $0,60,120,240,480,720$ and $960 \mathrm{~g} \mathrm{pot}^{-1}$ in the yield of Japanese cucumber (Natsuno Kagayaki hybrid), and they found that the maximum fruit yield $(1,660.15 \mathrm{~g}$ plant $^{-1}$ ) was achieved at the dose of $570 \mathrm{~g} \mathrm{pot}^{-1}$ $(59.38 \%)$. However, the authors do not mention whether the cattle manure was composted. In the present study, the highest amount of cattle manure (100\%) had a yield of $1395.3 \mathrm{~g} \mathrm{plant}^{-1}$, and the use of $100 \%$ of cattle manure for the seedling formation and fruit production was not a limiting factor.

Table 3. Interactions between substrates and cultivars for fruit mass (FM), fruit diameter (FD), number of fruits (NF), and yield per plant (YP) of cucumber cultivars. Aquidauana-MS, UEMS, 2011.

\begin{tabular}{|c|c|c|c|c|c|c|}
\hline & Marketer & Caipira & Verde comprido & Marketer & Caipira & Verde comprido \\
\hline & \multicolumn{3}{|c|}{ FM (kg) } & \multicolumn{3}{|c|}{$\mathrm{FD}(\mathrm{mm})$} \\
\hline $75 \% \mathrm{CS}+25 \% \mathrm{CM}$ & $0.182 \mathrm{Aa}$ & $0.184 \mathrm{Ba}$ & $0.190 \mathrm{Aa}$ & $42.57 \mathrm{Aa}$ & $43.70 \mathrm{Ba}$ & $40.75 \mathrm{Aa}$ \\
\hline $50 \% \mathrm{CS}+50 \% \mathrm{CM}$ & $0.186 \mathrm{Aa}$ & $0.188 \mathrm{Ba}$ & $0.185 \mathrm{Aa}$ & $42.18 \mathrm{Aa}$ & $42.85 \mathrm{Ba}$ & $43.48 \mathrm{Aa}$ \\
\hline $25 \% \mathrm{CS}+75 \% \mathrm{CM}$ & $0.161 \mathrm{Ab}$ & $0.230 \mathrm{Aa}$ & $0.167 \mathrm{Ab}$ & $40.05 \mathrm{Ab}$ & $50.35 \mathrm{Aa}$ & $42.69 \mathrm{Ab}$ \\
\hline $0 \% \mathrm{CS}+100 \% \mathrm{CM}$ & $0.175 \mathrm{Aab}$ & $0.206 \mathrm{ABa}$ & $0.163 \mathrm{Ab}$ & $42.36 \mathrm{Aab}$ & $46.48 \mathrm{ABa}$ & $40.74 \mathrm{Ab}$ \\
\hline $\mathrm{CV}(\%)$ & \multicolumn{3}{|c|}{11.46} & \multicolumn{3}{|c|}{7.58} \\
\hline $\mathrm{Pr}>\mathrm{Fc}$ & \multicolumn{3}{|c|}{0.0026} & \multicolumn{3}{|c|}{0.0165} \\
\hline & \multicolumn{3}{|c|}{$\mathrm{NF}$} & \multicolumn{3}{|c|}{ YP $\left(\right.$ kg plant $\left.^{-1}\right)$} \\
\hline $75 \% \mathrm{CS}+25 \% \mathrm{CM}$ & $0.90 \mathrm{Ba}$ & $0.10 \mathrm{Ba}$ & $1.00 \mathrm{Ca}$ & \multicolumn{3}{|c|}{$0.1168 \mathrm{~B}$} \\
\hline $50 \% \mathrm{CS}+50 \% \mathrm{CM}$ & $2.10 \mathrm{Bab}$ & $0.80 \mathrm{Bb}$ & $4.50 \mathrm{Ba}$ & \multicolumn{3}{|c|}{$0.4172 \mathrm{~B}$} \\
\hline $25 \% \mathrm{CS}+75 \% \mathrm{CM}$ & $10.60 \mathrm{Aa}$ & $3.90 \mathrm{Ab}$ & $8.30 \mathrm{Aa}$ & \multicolumn{3}{|c|}{$1.2557 \mathrm{~A}$} \\
\hline $0 \% \mathrm{CS}+100 \% \mathrm{CM}$ & $8.30 \mathrm{Aa}$ & $6.40 \mathrm{Aa}$ & $8.50 \mathrm{Aa}$ & \multicolumn{3}{|c|}{$1.3953 \mathrm{~A}$} \\
\hline $\mathrm{CV}(\%)$ & \multicolumn{3}{|c|}{37.98} & \multicolumn{3}{|c|}{44.18} \\
\hline $\mathrm{Pr}>\mathrm{Fc}$ & \multicolumn{3}{|c|}{0.0044} & \multicolumn{3}{|c|}{0.1824} \\
\hline
\end{tabular}

*Equal uppercase letters in the columns and lowercase letters in the rows do not differ from each other by the Tukey test at 5\% probability level $; \mathrm{CV}=$ coefficient of variation; $\mathrm{CS}=$ cassava stems; $\mathrm{CM}=$ cattle manure $\mathrm{Pr}=$ probability; $\mathrm{Fc}=\mathrm{F}$ calculated.

\section{Conclusions}

There was little influence of substrates on the emergence of cucumber cultivars.

Substrates with $75 \%$ and $100 \%$ of cattle manure are indicated for seedling formation as well as for fruit production of cucumber.

In the best substrates, cultivar Caipira had fruits with a larger mass and average fruit diameter, but in a smaller number.

\section{Acknowledgments}

"This study was financed in part by the Coordenação de Aperfeiçoamento de Pessoal de Nível Superior Brasil (CAPES) - Finance Code 001". To CNPq Proc. $\mathrm{N}^{\mathrm{o}} 300829 / 2012-4$ and To FUNDECT, proc. $\mathrm{n}^{\mathrm{o}}$ 23/200.647/2012 (Edital Chamada FUNDECT/CNPq $\mathrm{N}^{\circ}$ 05/2011 - PPP - Programa Primeiros Projetos). 


\section{Bibliographic References}

Antunes, G., Ferreira, A.P.S., Puiatti, M., Cecon, P.R., Silva, G.C.C., 2014. Produtividade e qualidade de frutos de pepino africano em resposta à adubação nitrogenada. Revista Ceres, 61(1), 141-146.

Araújo Neto, S.E., Azevedo, J.M.A., Galvão, R.O., Oliveira, E.B.L., Ferreira, R.L.F., 2009. Produção de muda orgânica de pimentão com diferentes substratos. Ciência Rural, 39(5), 1408-1413.

Cañizares, K.A., Costa, P.C., Goto, R., Vieira, A.R.M., 2002. Desenvolvimento de mudas de pepino em diferentes substratos com e sem uso de solução nutritiva. Horticultura brasileira, 20(2), 227-229.

Carrijo, O.A., Vidal, M.C., Reis, N.V.B., Souza, R.B., Makishima, N., 2004. Produtividade do tomateiro em diferentes substratos e modelos de casas de vegetação. Horticultura Brasileira, 22(1), 05-09.

Costa, E., Durante, L.G.Y., Nagel, P.L., Ferreira, C.R., Santos, A., 2011. Qualidade de mudas de berinjela submetida a diferentes métodos de produção. Revista Ciência Agronômica, 42(4), 1017-1025.

Costa, E., Durante, L.G.Y., Santos, A., Ferreira, C.R., 2013a. Production of eggplant from seedlings produced in different environments, containers and substrates. Horticultura Brasileira, 31(1), 139-146.

Costa, E., Leal, P.A.M., Gomes V.A., Machado, D., Jara, M.C.S., 2010. Biomassa de mudas de pepinos híbridos conduzidos sob ambientes protegidos. Bragantia, 69(2), 381386.

Costa, E., Pegorare, A.B., Leal, P.A., Espíndola, J.S., Salamene, L.C.P., 2012a. Formação de mudas e produção de frutos de berinjela. Científica, 40(1), 12-20.

Costa, E., Souza, T.G.S., Benteo, G.L., Benett, K.S.S., Benett, C.G.S., 2013b. Okra seedlings production in protected environment, testing substrates and producing fruits in field. Horticultura Brasileira, 31(1), 8-14.

Costa, E., Vieira, L.C.R., Leal, P.A.M., Jara, M.C.S., Silva, P.N.L., 2012b. Substrate with Organosuper for cucumber seedlings formation in protected environments and polystyrene trays. Engenharia Agrícola, 32(2), 226-235.

Costa, L.M., Andrade, J.W.S., Rocha, A.C., Souza, L.P., Neto, J.F., 2009. Avaliação de diferentes substratos para o cultivo de pepino. Global Science And Technology, 2(2), 21-26.

Echer, M.M., Guimarães, V.F., Aranda, A.N., Bortolazzo, E.D., Braga, J.S., 2007. Avaliação de mudas de beterraba em função do substrato e do tipo de bandeja. Semina: Ciências Agrárias, 28(1), 45-50.

Fernandes, A.A., Martinez, H.E.P., Oliveira, L.R., 2002. Produtividade, qualidade dos frutos e estado nutricional de plantas de pepino, cultivadas em hidroponia, em função das fontes de nutrientes. Horticultura Brasileira, 20(4), 571-575.

Fonseca, E.P., Valéri, S.V., Miglioranza, E., Fonseca, N.A.N., Couto, L., 2002. Padrão de qualidade de mudas de Trema micranta (L.) Blume, produzidas sob diferentes períodos de sombreamento. Revisa Árvore, 26(4), 515-523.
Gomes, J.M., Paiva, H.N., 2012. Viveiros florestais: propagação sexuada. Editora UFV, Viçosa-MG.

Guimarães, V.F., Echer, M.M., Minami, K., 2002. Métodos de produção de mudas, distribuição de matéria seca produtividade de plântulas de beterraba. Horticultura Brasileira, 20(3), 505-509.

Leal, P.A.M., Costa, E., Schiavo, J.A., Pegorare, A.B., 2011. Formação de mudas e produção a campo de beterraba e alface em Aquidauana-MS. Horticultura Brasileira, 29(2), 457-463.

Miranda, S.M., Ribeiro, R.L.D., Ricci, M.S.F., Almeida, D.L., 1998. Avaliação de substratos alternativos para produção de mudas de alface em bandejas. Seropédica-RJ: Embrapa Agrobiologia. 6 p. (Embrapa Agrobiologia. Comunicado Técnico, 24).

Modolo, V.A., Tessarioli Neto, J., Ortigozza, L.E.R., 1999. Desenvolvimento de mudas de quiabeiro (Abelmoschusesculentus (L.) Moench) em diferentes tipos de bandeja e substrato. Scientia agrícola, 56(2), 377-381.

Modolo, V.A., Tessarioli Neto, J., Ortigozza, L.E.R., 2001. Produção de frutos de quiabeiro a partir de mudas produzidas em diferentes tipos de bandejas e substratos. Horticultura Brasileira, 19(1), 39-42.

Oliveira, F.A., Medeiros, J.F., Oliveira, M.K.T., Lima, C.J.G.S., Galvão, D.C., 2007. Desenvolvimento de plantas de pepino sob diferentes teores de esterco bovino. Revista Verde, $2(2), 73-78$

Rodrigues, E.T., Leal, P.A.M., Costa, E., Paula, T.S., Gomes, V.A., 2010. Produção de mudas de tomateiro em diferentes substratos e recipientes em ambiente protegido. Horticultura Brasileira, 28(4), 483-488.

Rodrigues, G.S.O., Torres, S.B., Linhares, P.C.F., Freitas, R.S., Maracajá, P.B., 2008. Quantidade de esterco bovino no desempenho agronômico da rúcula (Eruca sativa L.), cultivar cultivada. Revista Caatinga, 21(1), 162-168.

Salles, J.S., Lima, A.H.F., Costa, E., 2017. Mudas de jambolão sob níveis de sombreamento, bancadas refletoras e profundidade de semeadura. Revista de Agricultura Neotropical, 4(Supl. 1), 110-118.

Seabra Júnior, S., Gadum, J., Cardoso, A.I.I., 2004. Produção de pepino em função da idade das mudas produzidas em recipientes com diferentes volumes de substrato. Horticultura brasileira, 22(3), 610-613.

Sediyama, M.A.N., Nascimento, J.L.M., Santos, M.R., Vidigal, S.M., Carvalho, I.P.L., 2012. Produção de pepino tipo japonês em ambiente protegido em função de adubação orgânica. Revista Brasileira de Agropecuária Sustentável, 2(2), 65-74.

Setubal, J.W., Belfort, C.C., Melo, M.V.S., 2004. Efeito de diferentes substratos na qualidade de mudas de pimentão. Horticultura Brasileira, 22(2), 403-408.

Silva, B.L.B., Costa, E., Binotti, F., Benett, C., Silva, A., 2018a. Qualidade e crescimento de mudas de achachairu em função do substrato e sombreamento. Pesquisa Agropecuária Tropical (Agricultural Research in the Tropics), 48(4), 407413. 
Silva, B.L.B., Costa, E., Salles, J.S., Binotti, F.F.S., Benett, C., 2018b. Protected environments and substrates for achachairu seedlings. Engenharia Agrícola, 38(3), 309-318.
Smiderle, O.J., Salibe, A.B., Hayashi, A.H., Minami, K., 2001. Produção de mudas de alface, pepino e pimentão em substratos combinando areia, solo e Plantmax ${ }^{\circledR}$. Horticultura Brasileira, 19(3), 253-257. 